\title{
ITLN1 wt Allele
}

National Cancer Institute

\section{Source}

National Cancer Institute. ITLN1 wt Allele. NCI Thesaurus. Code C124077.

Human IT LN1 wild-type allele is located in the vicinity of $1 \mathrm{q} 21.3$ and is approximately $9 \mathrm{~kb}$ in length. This allele, which encodes intelectin-1 protein, plays a role in the regulation of insulin-mediated glucose uptake. 